HISTOPATHOLOGICAL SPECTRUM OF LESIONS OF CERVIX IN A TERTIARY CARE HOSPITAL: A RETROSPECTIVE STUDY

\title{
Pathology
}

Sujeeva Swapna Reddythota

Siva Sankar Naik V

Neeraja M

\section{Bhavani C*}

\section{Jhansi Rani C}

Associate Professor Of Pathology, Department Of Pathology Government Medical College Ananthapuramu.

Associate Professor Of Pathology, Department Of Pathology Government Medical College Ananthapuramu.

Professor \& HOD Pathology, Department Of Pathology Government Medical College Ananthapuramu.

Associate Professor Of Pathology Department Of Pathology Government Medical College Ananthapuramu. *Corresponding Author

Assistant Professor of Biochemistry, Gandhi Medical College, Hyderabad

\section{ABSTRACT}

INTRODUCTION: Majority of the specimens which reach the histopathology laboratory are from gynecology department. The accessibility of the cervix to direct examination makes it the object of intensive and large scale study. Various inflammatory as well as infectious lesions are common in uterine cervix due to vulnerability to sexual trauma and being an easy access to various infections. Cervical cancer is one of the most frequently seen cancer in women in India.

AIM: The present study is aimed to find out the most common types of the cervical lesions, incidence and histological variants of malignancies in women so as to understand the distribution of various diseases.

MATERIALAND METHODS: This is a retrospective study done in Government Medical College , Ananthapuram, a Tertiary Care Centre, for a period of 2 years, from January 2017 to December 2018.

RESULTS: A total of 448 cases were retrieved from histopathology department and evaluated. The age group of the patients was between 20 80 years. There was about $388(86.6 \%)$ cases were non-neoplastic and $60(13.39 \%)$ cases were neoplastic.

CONCLUSION: The most common of non neoplastic lesions was chronic non-specific cervicitis. Most common neoplastic lesion was squamous cell carcinoma.

\section{KEYWORDS}

Cervicitis, neoplastic, non-neoplastic, squamous cell carcinoma.

\section{INTRODUCTION:}

The uterine cervix is prone for several non neoplastic and neoplastic lesions. Majority of the non-neoplastic lesions are inflammatory in nature. [1] Inflammatory lesions are common due to vulnerability to sexual trauma and being an easy access to various infectious organisms like bacteria, virus, protozoa and fungus. HPV cervicitis is a causal risk factor for condyloma acuminatum, preinvasive cervical intraepithelial neoplasia (CIN 1, 2, 3) and eventually cancer.(2) Carcinoma of the female genital tract particularly cancer of cervix accounts for almost $2 \%$ all cancers in women, and so represents the second most frequent gynaecological malignancy in the world. (3) In India, 90,000 of new cases of cervical cancer occur every year (4).

Cervical Intraepithelial Neoplasia most commonly occurs on the cervix at the squamo-columnar junction, but can also occur in vaginal walls and vulvar epithelium. Like other intraepithelial neoplasias, CIN or [SIL] is not cancer, and it is usually curable(.5). But if left untreated, a small percentage of cases can lead to invasive carcinoma.(6)

\section{MATERIALS AND METHODS :}

All the Hysterectomy specimens received at the Department of Pathology GMC, ANATHAPUR, over a period of $2 \mathrm{yrs}$. from Jan. 2017 to Dec. 2018 were included in the study. The specimens were sent from Obstetrics and Gynecology department. Slides were retrieved from of the archives of the department of pathology. Wherever necessary new sections were made from formalin fixed paraffin embedded blocks and stained with Haematoxylin and Eosin. Tumors of cervix were classified and studied according to WHO classification (2001)

\section{RESULTS:}

During this two years study period between Jan 2017 to Dec 2018, total 448 hysterectomy specimens were received in the department of pathology.

Table-1:Types of hysterectomy specimens received in the department of pathology.

\begin{tabular}{|c|c|c|}
\hline TYPE OF SPECIMEN & NO.OF CASES(448) & $\mathbf{\%}$ \\
\hline SIMPLE HYSTERECTOMY & 155 & $34.60 \%$ \\
\hline $\begin{array}{c}\text { HYSTERECTOMY WITH ONE } \\
\text { SIDED ADNEXAE }\end{array}$ & 20 & $4.46 \%$ \\
\hline
\end{tabular}

\begin{tabular}{|c|c|c|}
\hline $\begin{array}{c}\text { HYSTERECTOMY WITH BOTH SIDED } \\
\text { ADNEXAE }\end{array}$ & 273 & $60.94 \%$ \\
\hline
\end{tabular}

Out of 448cases, $388(86.6 \%)$ cases were non-neoplastic and 60 $(13.39 \%)$ cases were neoplastic.

Incidence of non-neoplastic lesions was higher than neoplastic lesions. Majority of cervical lesions were in the 5th decade (41.51\%). Chronic non-specific cervicitis with or without squamous metaplasia was the most common histological diagnosis made (51\%). Cervical Prolapse cases were occupying next position(31\%).

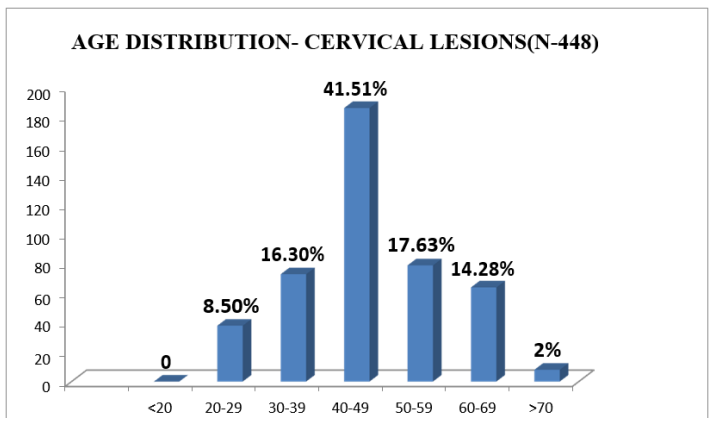

Chart-1: Bar diagram showing age distribution of cervical lesions. SPECTRUM OF LESIONS OF CERVIX (N=448)

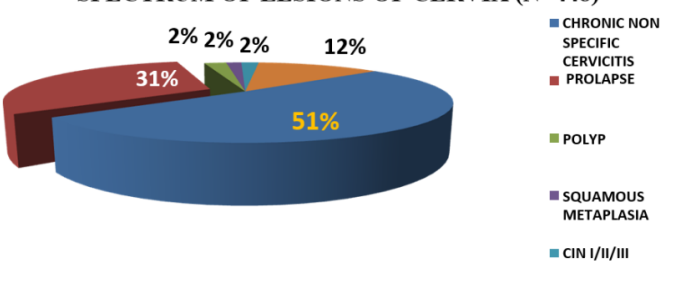

Chart - 2: Pie diagram showing histological spectrum of cervical lesions. 
AGE DISTRIBUTION OF CERVICAL MALIGNANCY(N=56)

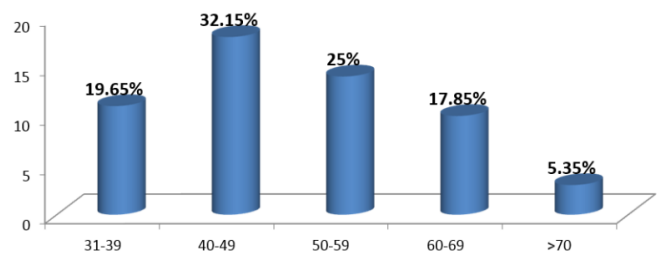

Chart- 3: Bar diagram showing age distribution of cervical malignancy

Among the neoplastic, malignant were 56 (12.5\%). Most common age group affected are 5 th decade $(32.15 \%)$. Moderately differentiated squamous cell carcinoma was the most common histological variant $(46.40 \%)$, followed by well differentiated SCC $(37.50 \%)$. No cases occurred before 30 years and 3 cases $(5.35 \%)$ after 70 years of age.

\section{HISTOLOGICAL TYPES OF CERVICAL MALIGNANCY( $\mathrm{N}=56)$}

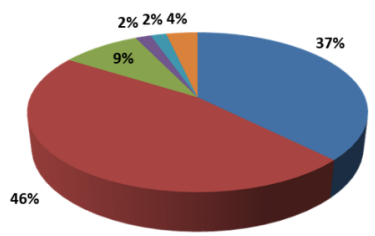

- WELL DiFFeRENTIATED SCC

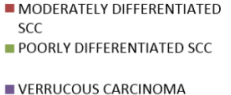

- ADENOSQUAMOUS CARCINOMA

- ADENO CARCINOMA

Chart - 4: Pie chart showing distribution of cervical malignant lesions.

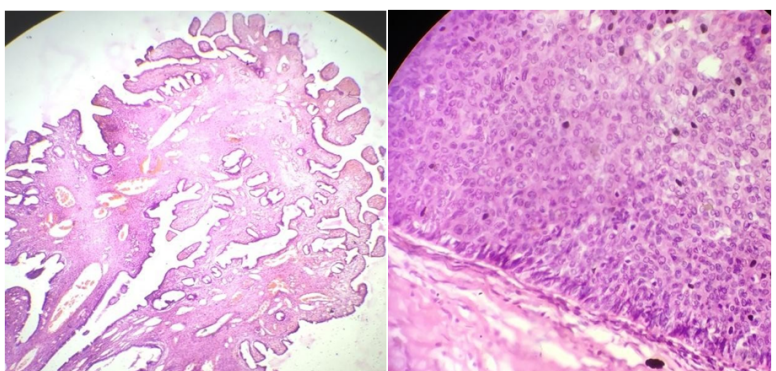

Fig-1: Endocervical polyp H\&E 4X.

Fig-2: High Grade Squamous

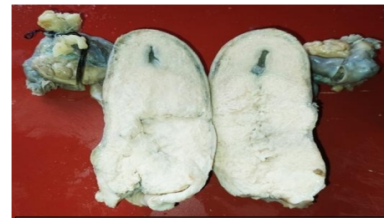

Fig-3: Gross Specimen of Carcinoma Cervix.

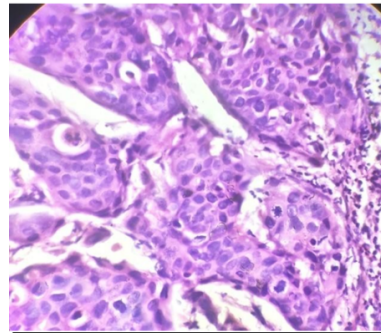

Fig-4: Well Differentiated

Squamous Cell Carcinoma H\&e 40x.

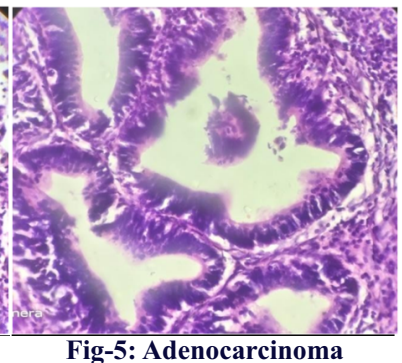
cervix $H \& E$ 40X

\section{DISCUSSION}

Cervices, continues to form the major bulk of gynecological specimens which are received in the histopathology department even after the incidence of carcinoma cervix has declined in the industrialized countries.(7) Chronic non-specific cervicitis constituted the majority of cervical lesions, with about $229(51 \%)$ cases being reported during the study period. This is not surprising because it is a frequently encountered condition both clinically and in histopathological specimens.(8).Also chronic non-specific cervicitis occurred between the age ranges of 20-80 years with a peak incidence at the 5 th decade of life. No case was seen before menarche.This is similar to the previous reports by Craig and Lowe.(9) . It is a common phenomenon in postmenopausal women. Certain lesions of chronic nonspecific cervicitis had coexisting squamous metaplasia. All the prolapsed cervix (31\%) cases had features of hyperkeratosis, with or without erosion. This condition constituted the second most common non-neoplastic lesion followed by chronic nonspecific cervicitis $(51 \%)$.

Non-inflammatory tumor like condition such as endocervical polyp was a rare entity, constituting only $2.20 \%$ of the total cervical specimens studied. The histological diagnosis of endocervical polyp was based on the presence of dilated endocervical glands and thick blood vessels in the stroma. Leiomyomatous polyp were 4 cases out of 10 cervical polyp cases.

The peak incidence of neoplastic lesion of the cervix was in 5 th decade. Cervical intraepithelial neoplasia included all cases of CIN 1, CIN 2 and CIN 3. Out of 448 cases only $7(1.78 \%$ ) cases of CIN (including CIN1, 2 \& 3) were diagnosed based on the typical histological findings. Highest incidence of CIN was in the 6th decade. Our study shows highest incidence of squamous cell carcinoma in the 5 th decade. This finding is similar to the study done by Dhakal et al[10]. The other histological variants include verrucous carcinoma, adenocarcinoma, adenosquamous type few cases had co-existing carcinoma in-situ changes Cancer that develops in the endocervix is usually adenocarcinoma. In addition, small percentages of cervical cancer cases are mixed versions of the above two and are called adenosquamous carcinomas or mixed carcinomas. In our study, percentage of squamous cell carcinoma was more (92\%) as compared to adenocarcinoma (4\%) which is comparable with study done by Haghdel M. et al., [11] Smith HO et al., [12] and Ijaiya MA et al. [13].

In present study, highest occurrence of moderately differentiated squamous cell carcinoma ( $46 \%$ ) was noted, which is comparable to the study done by Husin $\mathrm{N}$ et al.[14]highest occurrence of moderately differentiated squamous cell carcinoma $(44.9 \%)$ was noted and in study done by Abudu EK et al. [15] highest occurrence of well differentiated squamous cell carcinoma (39\%) was noted.

\section{CONCLUSION:}

Based on the results and methodology applied, we have concluded that the most common non-neoplastic cervical lesion was chronic nonspecific cervicitis and the most common neoplastic lesion was squamous cell carcinoma. Peak incidence was in the 5th decade. The present study highlights on the spectrum of lesions of the cervix which is further divided under various categories. These categories can provide the basis for identifying the etiology. The spectrum of cervical lesions is vast and therefore early detection and management of certain lesions can help in reducing the morbidity.

\section{REFERENCES:}

. Omoniyi-Esan OG, Osasan SA, Ojo OS. Non-neoplastic diseases of the cervix in Nigeria: A histopathological study. Afr Health Sci 2006; 6: 76-80.

Bosch FX, Lorinez A, Munoz N, Meijer CJ, Shah KV. The causal relationship between human papilloma virus and cervical cancer. J Clin Pathol 2002; 55: 244-65.

Hausen HZ, Papilloma viruses and cancer basic studies to clinical application, Nat Rev, 2002; 2:342.

4. Panday K, Bhagoliwal AJ, A cancer cervix need for mass surveillance program specially in rural areas, Obstet gynecol India, 2005; 55(5): 436-439.

5. Agorastos T, Miliaras D, Lambropoulos A, Chrisafi S, Kotsis A, Manthos A, Bontis (2005). "Detection and typing of human papillomavirus DNA in uterine cervices with coexistent grade I and grade III intraepithelial neoplasia: biologic progression or independent lesions?". Eur J Obstet Gynecol Reprod Biol. 121 (1): 99-103.

6. Murthy NS, Mathew A (February 2000). "Risk factors for pre-cancerous lesions of the cervix". European Journal of Cancer Prevention. 9 (1): 5-14.

Wright Ct, Ferenczy A. Benign diseases of the cervix. In: Kurman RT editor.Pathology of female genital tract. 5 th ed. New Delhi: Springer Verlag; 2002.Pg.225-252.

8. Lowe D, Slavin G. Non-neoplastic conditions of the cervix: In Fox H(Ed).Haines and Taylor: Obstetrical and Gynaecological pathology. 4th edition Churchill Livingstone Taylor: Obstetrical and Gynac

9. Craig P.Lowe D. Non-neoplastic lesions of the cervix.In: Fox H.Well M.editors. Haines and Taylor: Obstetrical and Gynaecological pathology.5th ed.Edinburgh: Churchil Livingstone; 2003 page 273-96.

10. Dhakal HP,Pradhan M, Histological pattern of gynaecological cancers,J Nepal Med Assoc, 2009; 48(176):301-305.

11. Haghdel M, Ardakany MS, Zeighami B, Invasive carcinoma of the uterine cervix in Iran, Int J Gynecol Obstet, 1999; 64: 265-2671

12. Smith HO, Tiffany MF, Qualls CR, Key CR, The rising incidence of adenocarcinoma 
relative to squamous cell carcinoma of the uterine cervix in the United States: A24 years population based study, Gynecol Oncol, 2000; 78:97-105.

13. Ijaiya MA, Aboyeji PA, Buhari MO, Cancer of the cervix in Ilorin, Nigeria West, Africen Journal of Medicin, 2004; 23(4): 25-30.

14. Husin N, Helali T, Domi M, Bedri S, Cervical cancer in women diagnosed at the national health laboratory, sudden: A call for screening, Sudan journal of medical science, 2011; (6): 183-190.

15. Abudu EK, Banjo AAF, Izegbu MC, J.Agboola AO, Anunobi CC, Jagun OE, Histopathological pattern of carcinoma of cervix in Olabisi Onabanjo University Teaching Hospital, Sagamu, Nigeria, Nig Ot j Hosp Med, 2006; 16(3): 35-40. 